\title{
The Effects of Cognitive Strategies i.e. Note-Making and Underlining on Iranian EFL Learners' Reading Comprehension
}

\author{
Dr. Amir Mahdavi \\ English Department, University of Guilan, Rasht-Guilan, Iran \\ E-mail:mahdavi1339@gmail.com \\ Sadaf Azimi (Corresponding author) \\ MA student at TEFL at Guilan University, Iran \\ E-mail: sadafazimi@yahoo.com
}

Received: 09-07- 2012

Accepted: 26-07- 2012

Published: 01-11- 2012

doi:10.7575/ijalel.v.1n.6p.1

URL: http://dx.doi.org/10.7575/ijalel.v.1n.6p.1

\begin{abstract}
The purpose of this study was to investigate the effects of using cognitive strategies namely note- making and underlining, on Iranian EFL learners' reading comprehension. In doing so, 60 female fourth year high school EFL learners were selected by means of the NELSON test (050A). They were then divided randomly into three groups, each group consisting of 20 homogeneous students: two experimental groups, and one control group. The experimental groups practiced note making (group A) and underlining reading strategies (group B) on the same reading materials while the control group received the placebo. Then, all the subjects in the three groups took the same reading comprehension test. The results of a One-way Analysis of Variance (ANOVA) and a post-hoc analysis of the Scheffe test showed that the learners who utilized note-making and underlining strategies outperformed the control group $(\mathrm{p}<.05)$. Furthermore, the experimental group who received note-making instruction revealed a higher efficiency than underlining group. As a result it can be concluded that note making and underlining have had positive effects on students' rate of reading comprehensibility.
\end{abstract}

Keywords: Cognitive Strategies, Note- Making, Underlining, Reading Comprehension

\section{Introduction}

Reading comprehension is specifically the basic goal for ESL/EFL students to gain an understanding of the world and of themselves, enabling them to think about and react to what they read (Tierney, 2005). According to Grabe (1991), reading is an essential skill and probably the most important skill for second language learners to master in academic contexts. Since reading comprehension has been distinctively important both in first and second/foreign language learning, reading strategies are of great interest to the field of reading research. Reading research in recent years has also shed light on the perception of strategies, and strategy use/training in reading comprehension. Since the 1970 s, there have been a variety of reading strategies advocated by second language learning theorists to teach students to read well (Carrell, 1989). Notable researchers such as Brown (2001), Baker (2004), and Flavell (1981) have studied several different aspects of the relationship between cognitive strategies and effective reading.

The main goal of the present study was to examine the effects of two cognitive strategies namely underlining and selective reading strategy (which includes selecting important parts of the text and making notes of the selected parts) on Iranian EFL learners' reading comprehension.

Underlining which is the devise authors use to help readers identify points in a text such as headings, previews, and enumeration, has mixed results in reading research. Several studies have reached the conclusion that linguistic variables as well as reader goals, interest, and teacher expectations in school settings had a significant effect on readers' use of underlining strategies to find out main ideas in a passage (Brown \& Day, 1983; 
International Journal of Applied Linguistics \& English Literature

ISSN 2200-3592 (Print), ISSN 2200-3452 (Online)

Vol. 1 No. 6; November 2012

Afflerbach, 1990; Van Hout-Wolters, 1990). Weinstein and Mayer (1985) called underlining as a complex rehearsal strategy.

Selecting important parts of the text and making notes based on the selected parts is another cognitive strategy which was examined in the present study. Making notes of the important parts of the text which have been selected by the readers is a cognitive learning strategy which can enhance EFL/ESL learners' language comprehension (Hismanoglu, 2000).

Although there may indeed exist various techniques and activities for improving learners' reading comprehension; the researcher of the present study has focused attention on two main cognitive strategies (underlining key words and selecting and making notes of important points).

This study is significant because it will help EFL learners improve their reading comprehension proficiency by the suggested reading comprehension strategies and doing many more activities related to these reading strategies. Moreover, it may prove to be pedagogical value in EFL classrooms and lead EFL instructors to provide learners with enough information to utilize these strategies in reading comprehension.

\section{Research Questions}

The specific research questions addressed in this study are:

(1) Does making notes of the selected parts of the passage improve Iranian female fourth year high school EFL learners' reading comprehension?

(2) Does underlining key words improve Iranian female fourth year high school EFL learners' reading comprehension?

(3) Is there any significant difference between the effects of making notes and underlining strategies on Iranian female fourth year high school EFL learners' reading comprehension ability?

\section{Method}

\subsection{The Design of the Study}

True experimental design was used in this study. The schematic representation of this design is shown below in table 1 .

Table 1. Schematic representation of study Experimental Design

\begin{tabular}{|l|l|l|}
\hline G1 (random) T1 (placebo) T2 & Control group & 20 EFL learners \\
\hline G2 (random) T1 X T2 & Experimental A, making notes & 20 EFL learners \\
\hline G3 (random) T1 X T2 & Experimental B, underlining key words & 20 EFL learners \\
\hline
\end{tabular}

T1=Pre-test, T2=Post-test

\subsection{Participants}

This experimental research was conducted through the participation of 60students who were selected (based on their performance on a NELSON test) out of 120 fourth grade high school learners in two high schools of Sangar, Guilan. The participants were females, who were selected from students of three majors (i.e. Natural Sciences, Human Sciences and Mathematics and Physics).

\subsection{Instruments and Materials}

In this study a number of instruments were used.

Tests: In order to answer the research questions two sets of tests were applied.

\section{a. Measure of L2 Proficiency NELSON}

A Nelson English Language Test (NELSON 050A) developed by Fowler \& Coe, (1976) was used as a means to homogenize the learners with regard to their language proficiency level.

\section{b. Pre- and Post -Test}

Two reading comprehension tests (150A as a pretest and $150 \mathrm{~B}$ as a posttest) developed by Fowler \& Coe, (1976) were utilized just to witness the initial reading comprehension proficiency of the learners in each group at the beginning of the study. 


\section{Instructional Materials}

\section{a. Reading passages}

The reading comprehension passages were chosen from the students' English textbook (Fourth year high school English text book, learning to read English for the pre- university students, Birjandi, Anani Sarab, Samimi, 1390).

\section{b. Treatment}

During 10 sessions, the selected cognitive strategies were demonstrated and modeled by the Cognitive Academic Language Learning Approach (CALLA), developed by Chamot and O’Malley (1994). This model included five instructional phases. First, the researcher defined the related strategies in context while reading for the experimental groups.

Second, the researcher modeled and practiced the selected strategies for an entire session for the two experimental groups. In this instructional phase, the students were given explicit, direct instruction in the use of the underlining strategy and making notes.

Third, the students practiced making notes (group A) and underlining strategy (group B) with familiar contexts and familiar tasks which were provided for them by the researcher; in subsequent strategy practice, the researcher encouraged independent strategy use. Also, the researcher provided scaffolding until they became independent.

Fourth, the students evaluated their own strategy use immediately after each practice session by checking the strategy they had used and monitoring their understanding. And fifth, to develop a larger repertoire of strategies, the students were asked to apply this strategy to new tasks.

\subsection{Data Collection Procedure}

This experimental research was conducted through the participation of 6 0students who were selected (based on their performance on a NELSON test) out of 120 grade four high school learners in two high schools. The participants were females, who were selected from students of three majors (i.e., Natural sciences, Human Sciences and Mathematics and Physics). This experiment was accomplished during regular class periods. The course consisted of 10 sessions and each week included two 90 minute sessions.

At the beginning of the study NELSON test $(050 \mathrm{~A})$ was used to homogenize the subjects in terms of their general foreign language proficiency. Then a multiple-choice cloze passage test developed by Fowler \& Coe, 1976 was administered to all three groups in their first session of reading course to ensure the homogeneity of the subjects in terms of their reading comprehension proficiency, too. The next step was to conduct the experimental treatment. Treatment sessions included a demonstration of the underlining strategy and making notes of the main issues based on the CALLA model. After the treatment sessions the subjects did a post-test taken from Fowler \& Coe, 1976.Finally, the results of both pre-test and post-test were compared for data analysis.

\section{Results}

At the beginning of the study all learners took part in the pre-test. The purpose was to establish a baseline from which gains in performance on the post-test could be measured. Results indicated no significant difference $(\mathrm{F}=$ $0.39, p(0.67)>0.05)$ in learners' performance on the pre-test among the control and treatment subjects (table 2).

Table 2. One Way ANOVA for the Three Groups on Pre-Test

\begin{tabular}{lccccc}
\hline & $\begin{array}{c}\text { Sum of } \\
\text { Squares }\end{array}$ & df & Mean Square & F & Sig. \\
\hline Between Groups & 36.93 & 2 & 18.46 & .39 & .67 \\
Within Groups & 2659.25 & 57 & 46.65 & & \\
Total & 2696.18 & 59 & & & \\
\hline
\end{tabular}




\section{International Journal of Applied Linguistics \& English Literature \\ ISSN 2200-3592 (Print), ISSN 2200-3452 (Online)}

Vol. 1 No. 6; November 2012

Considering the fact that the three groups were equal in terms of their reading comprehension proficiency at the beginning of the study, data from the post-test was used to compare and evaluate the effect of treatment. Another One Way ANOVA was conducted for the post -test scores.

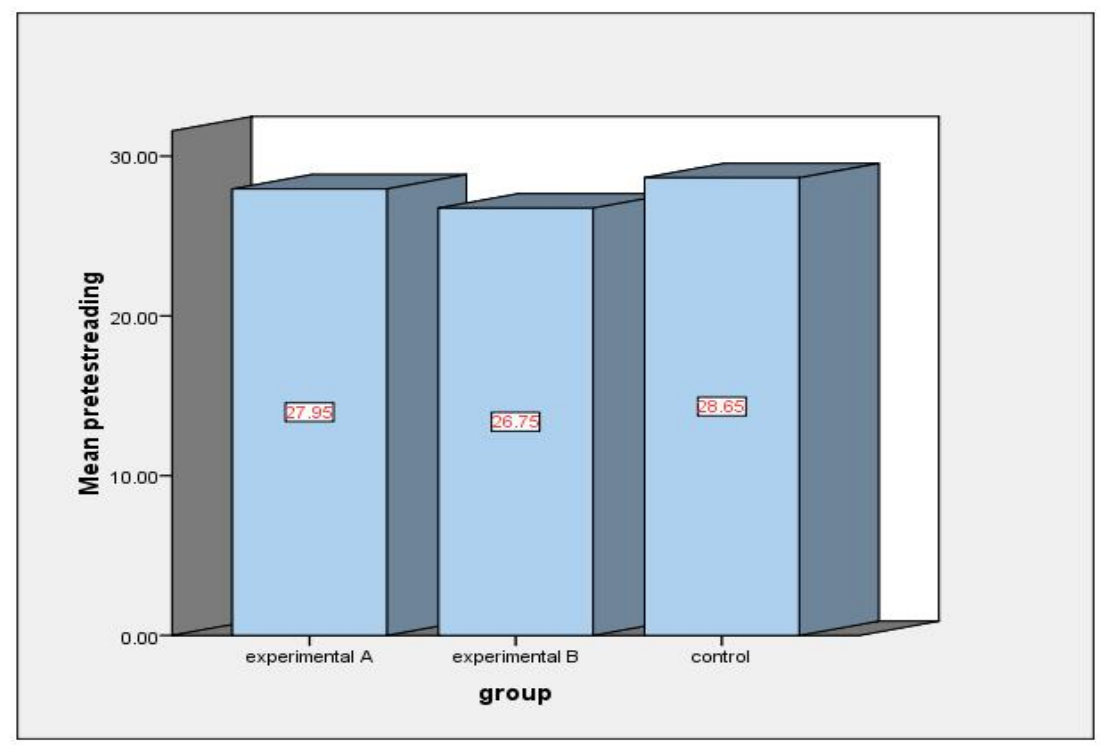

Figure 1. The Comparison of the Three Groups on Pre- Test

Table 3. One Way ANOVA for the Three Groups on Post-Test

\begin{tabular}{lrrrrr}
\hline & \multicolumn{1}{c}{$\begin{array}{l}\text { Sum of } \\
\text { Squares }\end{array}$} & df & Mean Square & \multicolumn{1}{l}{ F } & Sig. \\
& 1006.90 & 2 & 503.45 & 11.82 & .000 \\
Between Groups & 2426.35 & 57 & 42.56 & & \\
Within Groups & 3433.25 & 59 & & & \\
\hline
\end{tabular}

The relatively high value of $F=11.82$ showed that there was, indeed, a significant effect of cognitive strategy training on subjects' reading comprehension scores. Considering the ( $\mathrm{P}$ value), it can be claimed that this effect is also meaningful. To find out the location of the differences among the three groups, a Scheffe test was conducted the results of which are provided in the following table:

Table 4. Multiple Comparisons for the Three Groups on Post-Test

\begin{tabular}{llccccc}
\hline (I) group & (J) group & Mean Difference (I-J) & Std. Error & Sig. & \multicolumn{2}{c}{$95 \%$ Confidence Interval } \\
\cline { 4 - 7 } & & & & & Lower Bound & Upper Bound \\
\hline Experimental A & Experimental B & 3.85 & 2.06 & .18 & -1.33 & 9.03 \\
& Control & $9.95^{*}$ & 2.06 & .00 & 4.76 & 15.13 \\
\hline \multirow{2}{*}{ Experimental B } & Experimental A & -3.85 & 2.06 & .18 & -9.03 & 1.33 \\
& Control & $6.10^{*}$ & 2.06 & .01 & .91 & 11.28 \\
\hline \multirow{2}{*}{ Control } & Experimental A & $-9.95^{*}$ & 2.06 & .00 & -15.13 & -4.76 \\
& Experimental B & $-6.10^{*}$ & 2.06 & .01 & -11.28 & -.91 \\
\hline
\end{tabular}

*. The mean difference is significant at the 0.05 level. 


\section{International Journal of Applied Linguistics \& English Literature \\ ISSN 2200-3592 (Print), ISSN 2200-3452 (Online) \\ Vol. 1 No. 6; November 2012}

The results showed that although there was a meaningful difference among the three groups in terms of their reading score $(\mathrm{p}=0.00)$, the significant difference is only between the Experimental Group (A) and the Control Group ( $\mathrm{p}=0.00)$ and Experimental Group (B) and the Control Group (C) $(\mathrm{p}=0.01)$. considering the mean difference between groups (A) and (B), the findings indicate that the reading scores of the Experimental (A) and the Experimental (B) are not statistically significant $(p=0.18)$. In other words there was not a significant difference between the reading comprehension scores of the two experimental groups.

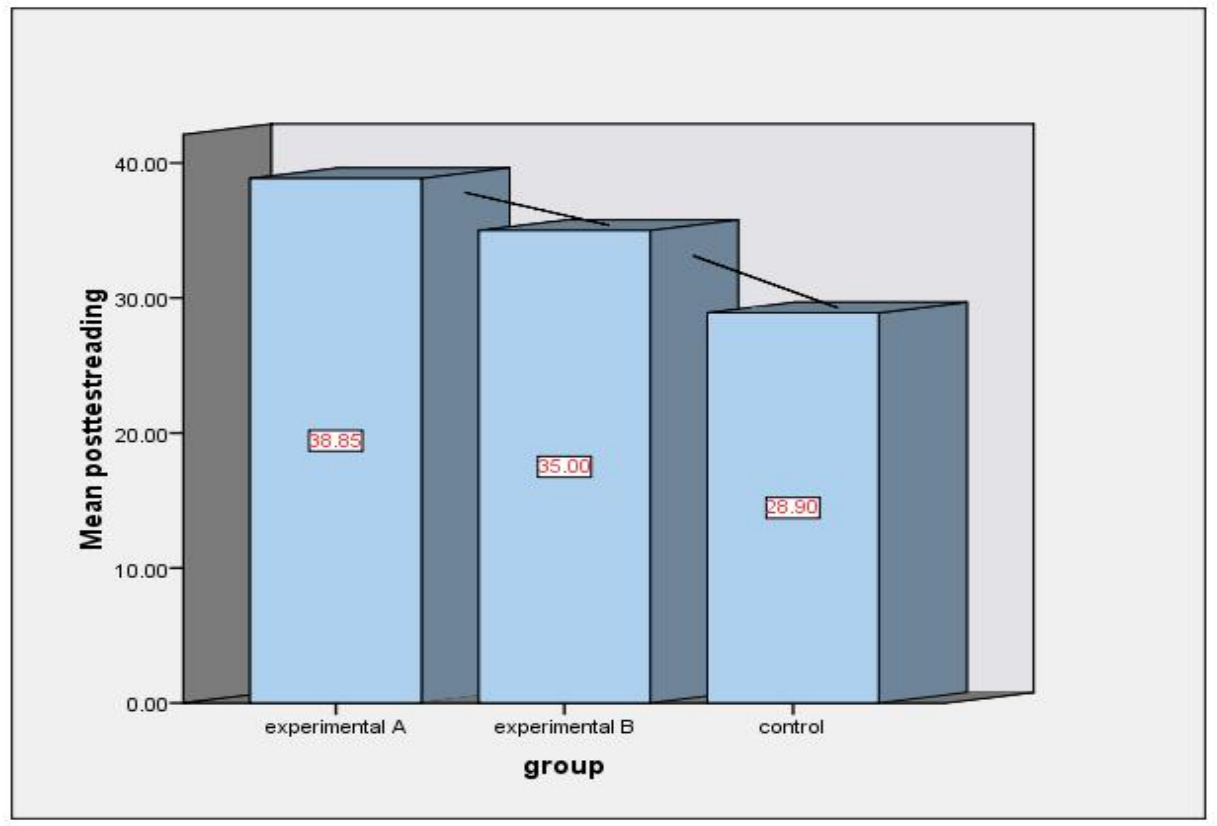

Figure 2. the Comparison of the Three Groups on Pre- Test

There were statistically significant differences between the groups that received strategy training and the group that received no strategy training on the post-test reading scores rejecting the null hypotheses one and two. However, there was no statistically significant difference between experimental (A) and experimental (B) groups on the post-test reading scores supporting hypothesis three that there is no significant difference between the two experimental groups in terms of their performance in post reading comprehension tests.

\section{Discussion and Conclusion}

Those participants who were applied reading strategies in comprehending passages may become better and more skillful readers since they used to employ reading strategies while reading a passage in the classroom in general. This is in line with the idea of Kern's $(1997$, p. 2) who noted that "strategic reading is a prime characteristic of expert readers because it is woven into the very fabric of reading for meaning."

The subjects who applied underlining key words reading strategy might receive the advantage of being able to predict the purpose of the passage, the main topic, or message, and possibly some of the developing or supporting ideas. This gives them a head start as they embark on more focused reading (Brown, 2001, pp. 308-309).

The results of this investigation might have implications for EFL teaching, testing and research programs. Based on the finding, the teachers are recommended to include note-making and underlining materials as part of their instruction to help students learn more about the subject matter under instruction (Boch \& Piolat, 2005). 


\section{International Journal of Applied Linguistics \& English Literature \\ ISSN 2200-3592 (Print), ISSN 2200-3452 (Online) \\ Vol. 1 No. 6; November 2012}

The exact appropriate time and level of education to start teaching reading strategies is also due for further research. Dunkel (1988) points out that the students' attitudinal factors such as interest, motivation, and previous knowledge influence strategy use. Other studies can examine these factors in relation to strategy use.

In summary, it can be conclusively said that this study has shown a significant positive effect of the determined cognitive strategies namely note making and underlining on Iranian EFL learners' reading comprehension, as measured by multiple choice questions.

\section{References}

Afflerbach, P., (1990). The influence of prior knowledge on expert readers' main idea construction strategies. Reading Research Quarterly, 25, pp. 31-46.

Baker, W. (2004). Learning strategies in reading and writing: EAP contexts. RELC Journal, 35(3), 299-328.

Boch, F. \& Piolat, A. (2005). Note taking and learning: A Summary of research. The WAC Journal, 16, 101-113. Brown, A. L., and J. D., Day, (1983). Macrorules for summarizing texts: The development of expertise, Journal of Verbal Learning and Verbal Behavior, 22, pp. 1-14.

Carrell, P. L., (1989). Metacognitive Awareness and Second Language Reading, the Modern Language Journal, 73(2), pp. 121-134.

Dunkel, P. (1988). The content of L1 and L2 students' lecture notes and its relation to test performance. TESOL Quarterly, 22, 259-281.

Flavell, J.H., Speer, J.R., Green, F.L. and August, D.L. (1981). The Development of Comprehension Monitoring and Knowledge about Communication, Monographs of the Society for Research in Child Development, 46(5), pp. 1-65.

Fowler, W. S., \& Coe, N. (1976). Nelson English Language Tests. London: Butler \& Tannerltad.

Grabe, W. (1991). Current developments in second language reading research. TESOL Quarterly. 25 (3): $375-406$

Hismanoglu, M. (2000). Language learning strategies in foreign language learning and teaching. The Internet TESL Journal, 6(8). http://iteslj.org/ .

Kern, R. G. (1997). L2 Reading Strategy Training: A Critical Perspective. Unpublished paper presented at the AAAL Conference, Orlando, Florida, March 10, 1997.

O’Malley, J. M., \& Chamot, A. U. (1990). Learning strategies in second language acquisition. Cambridge, NY: Cambridge University Press.

Singhal, M. (2001). Reading Proficiency, Reading Strategies, Metacognitive Awareness and L2 Readers. Reading Matrix, 1-9. Available at http :// www. reading matrix. com/articles/singhal/

Tierney, J. E. R. R. J., (2005). Reading Strategies and Practices (Sixth ed.). Boston: Pearson Education, Inc. Van Hout- Wolters, B. (1990). Teachers'selection of key phrases in instructional texts, Paper presented at the 40th annual meeting of the National Reading Conference in Miami, FL. 